\title{
Impact of Construction Productivity Attributes Over Construction Project Performance in Indian Construction Projects
}

\author{
Saurav Dixit ${ }^{1 *}$, Kinshuk Saurabh $^{2}$ \\ ${ }^{1}$ School of Construction, Faculty of Construction Project Management, RICS School of Built Environment, Amity University, \\ Noida, India, Sector - 125, Noida 201313 (UP) India \\ 2 Department of Finance, Faculty of Finance and Accounting, Indian Institute of Management (IIM) Nagpur, VNIT Campus, \\ South Ambazari Road, Nagpur-440010, Maharashtra, India \\ * Corresponding author, e-mail: sauravarambol@gmail.com
}

Received: 18 June 2018, Accepted: 27 August 2018, Published online: 30 April 2019

\begin{abstract}
Performance of a construction project could be influenced by a number of attributes, especially large and complex projects lay additional focus on the success / failure attributes, because of the intensive amount of money invested, a high degree of uncertainty, the complexity of personnel's required, a multiplicity of goals and problems in coordination between different stakeholders encountered. In this research paper, the author intended to define and examine the relationship and impact of construction productivity (CP) over construction project performance (CPP). The author tests the proposition that there is a positive relationship/impact between both of them. And to test the effect of factors is affecting CP on CPP and to propose a conceptual model on the basis of the analysis. To validate the mathematical validity of factor analysis, Spearman correlation analysis has been performed on the factors. And to check the reliability of all the factors using reliability analysis, and finally test the hypothesis that construction productivity is having a positive impact on project performance using one sample t-test. The findings of the study concluded that there is a positive impact of construction productivity on project performance in Indian construction projects. This paper attempts to identify the relationship between CP and CPP and recommends the framework for the industry to grow sustainably and deliver projects successfully. This study is conducted using a structured questionnaire survey in India and to validate the results of the study similar kind of study is required to be conducted in the other regions of the country to have more reliable findings.

"This paper is the revised version of the paper that has been published in the proceedings of the Creative Construction Conference 2018: Dixit, S., Mandal, S. N., Thanikal, J. V, \& Saurabh, K. (2018). Construction Productivity and Construction Project Performance in Indian Construction Projects, m(July), 379-386. https://doi.org/10.3311/CCC2018-050".
\end{abstract}

\section{Keywords}

construction productivity, construction project performance, impact, attributes, project management

\section{Introduction}

The construction sector is the engine of growth for any country and contributes about 8-10\% to the GDP on an average. Provide employment to masses and create a flow of services and goods with other sectors. The measures to be done to improve the performance of construction projects has been identified as critical and troublesome problems (Iyer and Jha, 2005). The construction industry faced a number of issues and low rates of productivity growth and declining growth have entertained a number of researchers for many years (Jones and Slinn, 1956). The firms are aware of this issue and start investing to know the causes tend the productivity remains low (Dixit et al., 2017a; 2017b).

The construction industry is having a significant importance in the economic, social, and infrastructure development of any country. It provides employment to the masses, promotes growth, and acts as a linkage to all the other sectors and the economy. Therefore the growth in the construction sector has a significant impact on the economy of the nation. Gains from higher construction productivity flow through the economy, as all industries rely on construction to some extent as part of their business investment. The construction sector 
is the engine of growth for any country and contributes about $8-10 \%$ to the GDP on an average (Iyer and Jha, 2005).

High productivity enables firms a sustainable advantage in comparison to their competitors and this is the main reason that a number of researchers study the concept and the attributes that affect construction productivity. The concept of productivity is the same in all countries but the findings of the one researcher can't be utilized to the different location or the country. There are some cultural, technological, political, policy, skills set and other issues that change from country to country. Productivity is been a vital issue of research since the time of industrialization. Productivity is considered to be one of the important measures of the economic growth of the nations (Singh et al., 2018). The construction industry having a significant contribution to the economy of the countries i.e. the contribution of the construction productivity to the productivity of the economy is to be considered significant in most of the economies.

Performance of a construction project is the measure of their health and at the end of the day, "the project is a successful project or a failed project". To answer this question either you have to track the project life cycle and draw the conclusions or either you can identify the success and failure cause for any construction project (this success or failure called attributes in this study). With the increase in the size of the project, the number of stakeholders associated with the project also increased. And the goals need not be the same of all the stakeholders associated with the project (Iyer and Jha, 2005). Performance of construction projects needed to be measured and improved. And the steps required to measure and improve the performance of projects are: first identify the attributes contributing to the success or failure of a construction project. A number of a researcher working in this area and mainly of them from developed countries. In developing countries a few articles or minor research papers been published on the performance of construction projects. The construction sector is the engine of growth for any country and contributes about $8-10 \%$ to the GDP on an average. Provide employment to masses and create a flow of services and goods with other sectors. The measures to be done to improve the performance of construction projects has been identified as critical and troublesome problems (Iyer and Jha, 2005).

In this research paper, the author intended to define and examine the relationship between construction productivity (CP) and construction project performance (CPP). The author tests the proposition that there is a positive relationship between both of them.

The hypothesis proposed for the study:

- (H0): There is no significant relationship between construction productivity attributes and Project performance.

- (Ha): There is a significant relationship between construction productivity attributes and Project performance.

In this paper, the introduction is revised and a few more concepts of construction productivity and project

Table 1 The issues and challenges in construction productivity(Dixit et al., 2018)

\begin{tabular}{|c|c|}
\hline Impacts & References \\
\hline $\begin{array}{l}\text { Construction industry experienced a downward trend } \\
\text { in the productivity growth }\end{array}$ & $\begin{array}{l}\text { (Abdel-Wahab and Vogl, 2011; Jones and Slinn, 1956; Chau, 2009; } \\
\text { Ruddock and Ruddock, 2011) }\end{array}$ \\
\hline $\begin{array}{l}\text { The study pertaining to causes of time, cost overruns and low } \\
\text { productivity in construction projects have been conducted worldwide }\end{array}$ & $\begin{array}{l}\text { (Ameh and Osegbo, 2011; Chiang et al., 2012; Muhwezi et al., 2014; } \\
\text { Zeithaml, 2000; Zouher Al-Sibaie et al., 2014) }\end{array}$ \\
\hline $\begin{array}{l}\text { The productivity of the UK's construction sector is declining and it is } \\
\text { lower than as compared to a few European countries }\end{array}$ & (Ameh and Osegbo, 2011; Best, 2010) \\
\hline $\begin{array}{l}\text { Construction productivity has been affected by a number of factors, } \\
\text { which tend to losses of revenues, delay in completion, poor quality } \\
\text { and other issues in construction projects }\end{array}$ & (Dixit et al., 2017b) \\
\hline $\begin{array}{l}\text { The decline in productivity is one of the dangers to the economy, } \\
\text { because it creates social conflict, and creates inflationary pressure }\end{array}$ & (Dyer et al., 2012; Xue et al., 2008) \\
\hline $\begin{array}{l}\text { The authors concluded that the growth in construction productivity } \\
\text { is negative }\end{array}$ & (Sveikauskas et al., 2016) \\
\hline $\begin{array}{l}\text { The author's observed that the industry shifting is also the reason } \\
\text { for low productivity }\end{array}$ & $\begin{array}{l}\text { (Abdel-Wahab and Vogl, 2011; Dyer et al., 2012; } \\
\text { Sveikauskas et al., 2016) }\end{array}$ \\
\hline $\begin{array}{l}\mathrm{CP} \text { is one of the main drivers for completing projects within time } \\
\text { and cost limitations }\end{array}$ & (Moselhi and Khan, 2010; 2012) \\
\hline $\begin{array}{l}\text { Appropriate estimation of CP is quite important for preparing } \\
\text { construction schedules and budgets }\end{array}$ & (Panas and Pantouvakis, 2010; 2015; Rashid, 2015) \\
\hline
\end{tabular}


performance has been included in the introduction. And the research methodology and findings of the study were updated and the extended analysis has been performed using descriptive statistics to make it much more comprehensive and sound in terms of the quality of the paper.

\section{Literature review}

The success of any project is repeatable and it is possible to find out a set of certain success attributes for the success of a construction project and it requires a controlled discipline hardworking (Iyer and Jha, 2005). The productivity of construction projects is one of the measures for performance of the construction projects at the industry level based on its relationship with economic development. And most countries encounter the issue of low productivity as per the statistical data available. Whereas growth in construction productivity is low and do not continue progressively for a long span of time. In construction projects, the partial measure of productivity is the measure of labor productivity, machine productivity and consumption of materials. These investigations run from hypothetical work in view of understanding of scientist toward one side to organized research deal with the other end. The tools used by the past researchers are AHP (analytical hierarchy process), structures to collect data, simulation models to predict the productivity, framework to improve productivity, techniques to measure productivity, and neural networks systems.

Performance of a project can be considered as a result of the processes as well as the presence of processes. Iyer and Jha (2005) and Jarkas et al. (2012) stated that construction time is important because it often serves as a benchmark for assessing the performance categories such as people, cost, time, quality, safety and health. Completing projects in a predictable manner of time (within schedule) is one of the important indicators of project success. Cost overrun is one of the most frequent problems with construction projects and contractors are criticized for the common occurrence of cost overrun in construction projects. There are some other factors which also contribute to the cost overrun such as profit of the project, project design cost, and wastage of materials, construction productivity, cost of variation orders and cost of rework.

\section{Research Methodology}

The methodology adopted for the study is to identify the factors affecting project performance form

Table 2 Summary of attributes / variables identified by previous researchers in the field of construction productivity (Dixit et al., 2018)

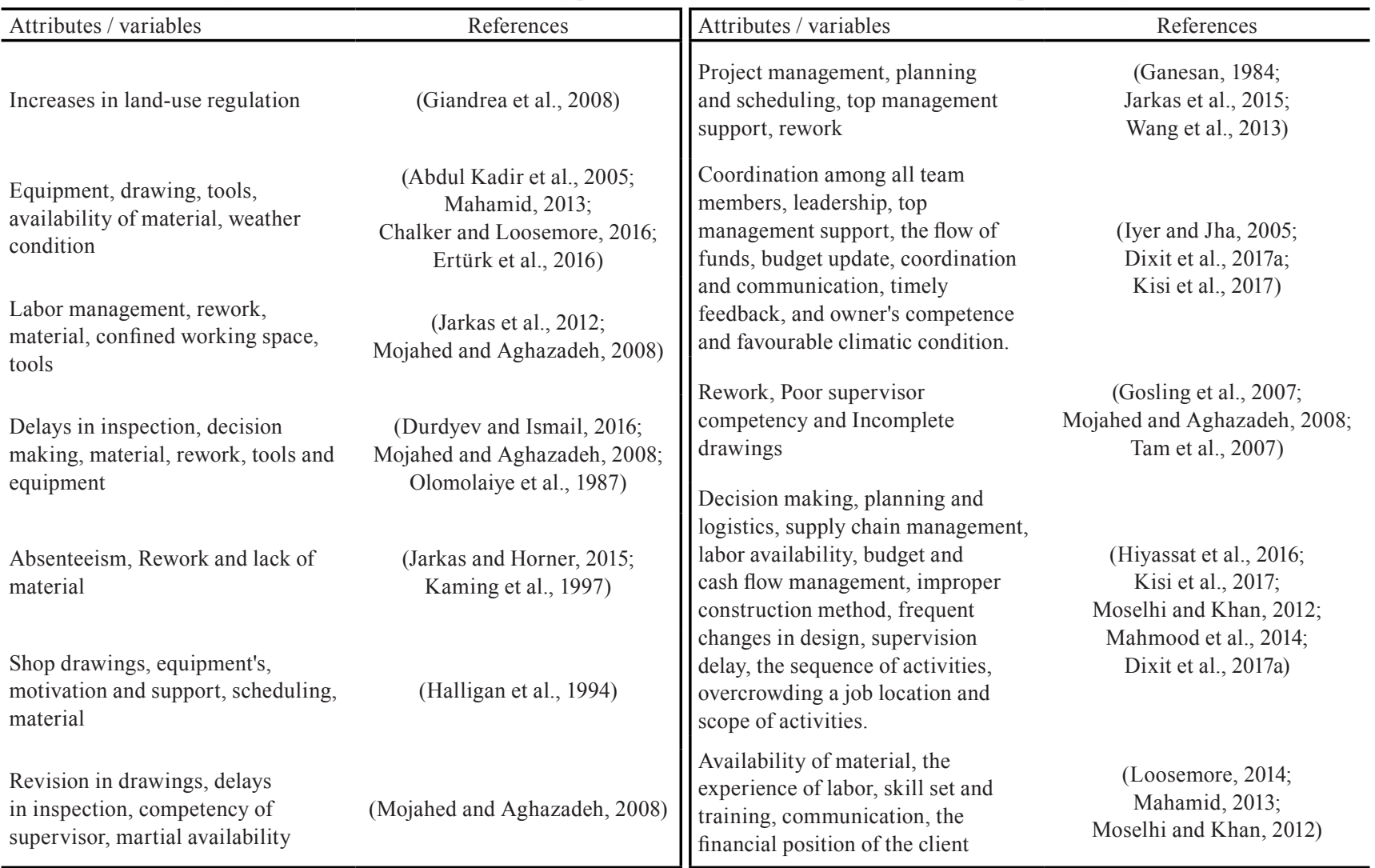


the literature review (to be specific from the paper "Construction Productivity and Construction Project Performance in Indian Construction Projects" (Dixit et al., 2018)) and the factors have been analyzed and explained in detail in this paper. This paper is the extended version of the previous paper and the statistical test applied to the paper are: correlation between the factors has been calculated and the factors have been analyzed, and the reliability analysis table for all the factors has been prepared to check the applicability of factor analysis, and one sample $t$-test is performed using SPSS 23 to check the hypothesis testing.

\subsection{Reliability analysis}

The value of reliability is in between 0 to 1 , the more near to 1 is more the reliable results (Iyer and Jha, 2005). Reliability analysis provides us with the confidence level that the data collected for the study is reliable and shall be used to generalize the findings of the study. The overall value of reliability for all the attributes is 0.765 (refer to Table 3) which is considered good to validate the findings (Singh et al., 2018).

\subsection{Factor analysis}

Factor analysis enables us to reduce the number of dimensions of the data and to draw a table on the basis of variance explained by the constructs / factors, and factor loading of the different attributes in factors. For the current study, the attributes having a factor loading of equal and more than 0.4 has been considered. The factor analysis reduced 26 attributes into 8 factors explain a cumulative variance of $62.3 \%$ in Table 4 (Dixit et al., 2018).

\subsection{Validating factor analysis}

The validation of factor analysis has been checked using the correlation in-between the attributes grouped to factor. The results of the correlation analysis conclude that

\begin{tabular}{lc}
\multicolumn{2}{c}{ Table 3 Reliability / Cronbach's alpha for the attributes } \\
\hline Reliability Cronbach's alpha for the attributes \\
\hline Attributes & Cronbach's alpha \\
All attributes selected for the study & 0.765 \\
Factor 1 & 0.79 \\
Factor 2 & 0.67 \\
Factor 3 & 0.605 \\
Factor 4 & 0.75 \\
Factor 5 & 0.714 \\
Factor 6 & 0.742 \\
Factor 7 & 0.735 \\
Factor 8 & 0.68 \\
\hline
\end{tabular}

Table 4 Factor analysis (Dixit et al., 2018)

\begin{tabular}{|c|c|c|}
\hline Attribute / Variable name & Factor loading & $\begin{array}{l}\% \text { age of } \\
\text { variance } \\
\text { explained }\end{array}$ \\
\hline Pre-construction management & & $14 \%$ \\
\hline $\begin{array}{l}\text { Inadequate formulation of the } \\
\text { project in the start }\end{array}$ & 0.65 & \\
\hline Contractual disputes & 0.85 & \\
\hline $\begin{array}{l}\text { Design capability and frequent } \\
\text { design changes }\end{array}$ & 0.80 & \\
\hline $\begin{array}{l}\text { Obsolete construction equipment, } \\
\text { and technology }\end{array}$ & 0.85 & \\
\hline $\begin{array}{l}\text { Labor and human resource } \\
\text { management }\end{array}$ & 0.67 & \\
\hline Financial management & & $10.3 \%$ \\
\hline $\begin{array}{l}\text { PM authority to make } \\
\text { financial decisions }\end{array}$ & 0.48 & \\
\hline Willingness to adopt change & 0.57 & \\
\hline $\begin{array}{l}\text { Availability of training and } \\
\text { development to enhance skills }\end{array}$ & 0.57 & \\
\hline $\begin{array}{l}\text { Use of inappropriate planning } \\
\text { tools and techniques }\end{array}$ & 0.54 & \\
\hline Claim geniuses & 0.46 & \\
\hline Socio-economic management & & $9.1 \%$ \\
\hline Quality & 0.55 & \\
\hline Supply chain & 0.79 & \\
\hline $\begin{array}{l}\text { Political and economic } \\
\text { environment }\end{array}$ & 0.61 & \\
\hline Social environment & 0.55 & \\
\hline Coordination and communication & & $7.1 \%$ \\
\hline Scope clarity of the project & 0.49 & \\
\hline $\begin{array}{l}\text { Coordination between } \\
\text { all stakeholders }\end{array}$ & 0.63 & \\
\hline $\begin{array}{l}\text { Developing and maintaining } \\
\text { communication }\end{array}$ & 0.49 & \\
\hline Project coordination meetings & 0.40 & \\
\hline Management of resources & & $6.3 \%$ \\
\hline $\begin{array}{l}\text { Timely payment of } \\
\text { completed works }\end{array}$ & -0.61 & \\
\hline Availability of resources & 0.40 & \\
\hline Commercial management & & $6 \%$ \\
\hline Regular budget update & 0.60 & \\
\hline $\begin{array}{l}\text { Conflict of interests among } \\
\text { team members }\end{array}$ & -0.40 & \\
\hline Top management support to PM & 0.57 & \\
\hline Site management & & $5.0 \%$ \\
\hline Site clearance / availability & 0.62 & \\
\hline Rework & & $4.3 \%$ \\
\hline Rework & -0.57 & \\
\hline Total variance explained & & $62.3 \%$ \\
\hline
\end{tabular}


the attributes grouped under factors having a minimum value of 0.4 or above. If the attributes were grouped in a factor they should be significantly correlated (Dixit et al., 2017b). The value of Pearson correlation has been tabulated in Tables 5-10. The Pearson correlation is calculated using SPSS 23.

\section{Conclusion and Recommendation}

The findings of independent one sample $t$-test having a value of ( $p$-value is 0.0 ) which is less than the significant value assigned for the hypothesis $(0.05)$. So the null hypothesis rejected, which concluded that; there is a significant relationship between construction productivity attributes and Project performance in Indian construction projects. The findings of the study conclude that the attributes / factors affecting / impacting construction productivity are directly impacting the performance of the project. This study provides a better understanding of the relationship between construction productivity and project performance in Indian construction projects. The future scope of the study is to propose a framework model using SEM (structural equation modelling) to improve construction productivity and to validate the model on different construction sites throughout India. The final results shall be the comparison between the productivity of projects before applying the model and the productivity after applying the model, and the conclusions to be drawn on the basis of variance in both samples.

\section{Limitation}

This paper attempts to identify the relationship between $\mathrm{CP}$ and CPP and recommends the framework for the industry to grow sustainably and deliver projects successfully. To validate the results of the study similar kind of study is required to be conducted in the other regions of the country to have more reliable findings.
Table 5 Pre-construction management

\begin{tabular}{cccccc}
\hline & R1 & R4 & R5 & R6 & R8 \\
\hline R1 & 1 & & & & \\
R4 & 0.41 & 1 & & & \\
R5 & 0.43 & 49 & 1 & & \\
R6 & 0.39 & 0.47 & 0.5 & 1 & \\
R8 & 0.45 & 0.42 & 0.47 & 46 & 1 \\
\hline
\end{tabular}

Table 6 Financial management

\begin{tabular}{lcccccc}
\hline & R10 & R17 & R20 & R25 & R9 & R19 \\
\hline R10 & 1 & & & & & \\
R17 & 0.51 & 1 & & & & \\
R20 & 0.45 & 0.44 & 1 & & & \\
R25 & 0.44 & 0.48 & 0.49 & 1 & & \\
R9 & 0.51 & 0.52 & 0.43 & 0.38 & 1 & \\
R19 & 0.43 & 0.46 & 0.47 & 0.39 & & 1 \\
\hline
\end{tabular}

Table 7 Socio-economic management

\begin{tabular}{cccc}
\hline & R13 & R14 & R15 \\
\hline R13 & 1 & & \\
R14 & 0.44 & 1 & \\
R15 & 0.46 & 0.41 & 1 \\
\hline
\end{tabular}

Table 8 Coordination and communication

\begin{tabular}{cccc}
\hline & R2 & R3 & R7 \\
\hline R2 & 1 & & \\
R3 & 0.47 & 1 & \\
R7 & 0.49 & 0.48 & 1 \\
\hline
\end{tabular}

Table 9 Management of resources

\begin{tabular}{ccc}
\hline & R21 & R22 \\
\hline R21 & 1 & \\
R22 & 0.57 & 1 \\
\hline
\end{tabular}

Table 10 Commercial management

\begin{tabular}{ccc}
\hline & R26 & R18 \\
\hline R26 & 1 & \\
R18 & 0.55 & 1 \\
\hline
\end{tabular}


Table 11 Hypothesis testing

\begin{tabular}{|c|c|c|c|c|c|c|}
\hline \multirow{2}{*}{ Attributes / Variables } & \multirow{2}{*}{$t$} & \multirow{2}{*}{$d f$} & \multirow{2}{*}{$\begin{array}{c}\text { Sig. } \\
\text { (2-tailed) }\end{array}$} & \multirow{2}{*}{$\begin{array}{c}\text { Mean } \\
\text { Difference }\end{array}$} & \multicolumn{2}{|c|}{$\begin{array}{l}95 \% \text { Confidence Interval of } \\
\text { the Difference }\end{array}$} \\
\hline & & & & & Lower & Upper \\
\hline Inadequate project formulation in the beginning & 19.223 & 124 & 0 & 2.128 & 1.9089 & 2.3471 \\
\hline Scope clarity of the project & 45.973 & 124 & 0 & 3.872 & 3.7053 & 4.0387 \\
\hline Coordination between all stakeholders & 40.209 & 124 & 0 & 4.096 & 3.8944 & 4.2976 \\
\hline Contractual disputes & 19.409 & 124 & 0 & 2.648 & 2.378 & 2.918 \\
\hline Design capability and frequent design changes & 21.856 & 124 & 0 & 2.104 & 1.9135 & 2.2945 \\
\hline Obsolete construction equipment's, methods and technology & 22.976 & 124 & 0 & 2.424 & 2.2152 & 2.6328 \\
\hline $\begin{array}{l}\text { Developing and maintaining a short and informal } \\
\text { line of communication }\end{array}$ & 44.845 & 124 & 0 & 3.688 & 3.5252 & 3.8508 \\
\hline Human resource and labor strike & 25.135 & 124 & 0 & 3.232 & 2.9775 & 3.4865 \\
\hline $\begin{array}{l}\text { Project managers authority to take financial decisions and } \\
\text { selecting key team members }\end{array}$ & 43.962 & 124 & 0 & 3.624 & 3.4608 & 3.7872 \\
\hline Timely payment of completed works & 42.196 & 124 & 0 & 3.816 & 3.637 & 3.995 \\
\hline Rework & 18.048 & 124 & 0 & 1.96 & 1.7451 & 2.1749 \\
\hline Site clearance / Availability & 38.147 & 122 & 0 & 3.357 & 3.1835 & 3.532 \\
\hline Quality & 29.866 & 124 & 0 & 3.432 & 3.2046 & 3.6594 \\
\hline Supply chain & 30.666 & 124 & 0 & 3.528 & 3.3003 & 3.7557 \\
\hline Political and economic environment & 25.545 & 124 & 0 & 3.296 & 3.0406 & 3.5514 \\
\hline Social environment & 34.6 & 124 & 0 & 3.528 & 3.3262 & 3.7298 \\
\hline Willingness to adopt change & 25.686 & 124 & 0 & 3.264 & 3.0125 & 3.5155 \\
\hline Conflict of interests among team members & 28.34 & 124 & 0 & 2.304 & 2.1431 & 2.4649 \\
\hline Claim genuine & 20.644 & 124 & 0 & 2.376 & 2.1482 & 2.6038 \\
\hline $\begin{array}{l}\text { Availability of training and development } \\
\text { for enhancing of skills }\end{array}$ & 35.596 & 124 & 0 & 3.808 & 3.5963 & 4.0197 \\
\hline Project coordination meetings & 50.362 & 124 & 0 & 4.192 & 4.0272 & 4.3568 \\
\hline Regular budget update & 44.32 & 124 & 0 & 3.72 & 3.5539 & 3.8861 \\
\hline Availability of resources & 69.47 & 124 & 0 & 3.816 & 3.7073 & 3.9247 \\
\hline Top management support to $\mathrm{pm}$ & 44.124 & 124 & 0 & 4.064 & 3.8817 & 4.2463 \\
\hline Use of inappropriate planning tools and techniques & 41.164 & 124 & 0 & 2.952 & 2.8101 & 3.0939 \\
\hline Availability of accurate historical information & 44.25 & 124 & 0 & 3.312 & 3.1639 & 3.4601 \\
\hline
\end{tabular}

\section{References}

Abdel-Wahab, M., Vogl, B. (2011) "Trends of productivity growth in the construction industry across Europe, US and Japan", Construction Management and Economics, 29(6), pp. 635-644. https://doi.org/10.1080/01446193.2011.573568

Abdul Kadir, M. R., Lee, W. P., Jaafar, M. S., Sapuan, S. M., Ali, A. A. A. (2005) "Factors affecting construction labour productivity for Malaysian residential projects", Structural Survey, 23(1), pp. 42-54. https://doi.org/10.1108/02630800510586907

Ameh, O. J., Osegbo, E. E. (2011) "Study of Relationship between Time Overrun and Productivity on Construction Sites", International Journal of Construction Supply Chain Management, 1(1), pp. 56-67. https://doi.org/10.14424/ijcscm101011-56-67

Best, R. (2010) "Using Purchasing Power Parity to Assess Construction Productivity", Australasian Journal of Construction Economics and Building, 10, pp. 1-10.

https://doi.org/10.5130/AJCEB.v10i4.1675
Chalker, M., Loosemore, M. (2016) "Trust and productivity in Australian construction projects: a subcontractor perspective", Engineering, Construction and Architectural Management, 23(2), pp. 192-210.

https://doi.org/10.1108/ECAM-06-2015-0090

Chau, K. W. (2009) "Explaining Total Factor Productivity Trend in Building Construction: Empirical Evidence from Hong Kong", International Journal of Construction Management, 9(2), pp. 45-54. https://doi.org/10.1080/15623599.2009.10773128

Chiang, Y. H., Li, J., Choi, T. N. Y., Fai Man, K. (2012) "Comparing China Mainland and China Hong Kong contractors' productive efficiency: A DEA Malmquist Productivity Index approach", Journal of Facilities Management, 10(3), pp. 179-197. https://doi.org/10.1108/14725961211245992 
Dixit, S., Mandal, S. N., Sawhney, A., Singh, S. (2017a) "Relationship between skill development and productivity in construction sector: A literature review", International Journal of Civil Engineering and Technology, 8(8), pp. 649-665. [online] Available at: http://www. iaeme.com/MasterAdmin/UploadFolder/IJCIET_08_08_066/ IJCIET_08_08_066.pdf [Accessed: 17 May 2018]

Dixit, S., Pandey, A. K., Mandal, S. N., Bansal, S. (2017b) "A Study of Enabling Factors Affecting Construction Productivity: Indian Scnerio", International Journal of Civil Engineering and Technology, 8(6), pp. 741-758. [online] Available at: http://www. iaeme.com/MasterAdmin/UploadFolder/IJCIET_08_06_080/ IJCIET_08_06_080.pdf [Accessed: 17 May 2018]

Dixit, S., Mandal, S. N., Thanikal, J. V, Saurabh, K. (2018) "Construction Productivity and Construction Project Performance in Indian Construction Projects", In: Creative Construction Conference, CCC 2018, Ljubljana, Slovenia, pp. 379-386. https://doi.org/10.3311/CCC2018-050

Durdyev, S., Ismail, S. (2016) "On-site construction productivity in Malaysian infrastructure projects", Structural Survey, 34(4-5), pp. $446-462$.

https://doi.org/10.1108/SS-12-2015-0058

Dyer, B., Goodrum, P. M., Viele, K. (2012) "Effects of Omitted Variable Bias on Construction Real Output and Its Implications on Productivity Trends in the United States", Journal of Construction Engineering and Management, 138(4), pp. 558-566. https://doi.org/10.1061/(ASCE)CO.1943-7862.0000460

Ertürk, M., Tuerdi, M., Wujiabudula, A. (2016) "The Effects of Six Sigma Approach on Business Performance: A Study of White Goods (Home Appliances) Sector in Turkey", Procedia - Social and Behavioral Sciences, 229, pp. 444-452. https://doi.org/10.1016/j.sbspro.2016.07.154

Ganesan, S. (1984) "Construction Productivity", Habitat International, 8(3-4), pp. 29-42. https://doi.org/10.1016/0197-3975(84)90041-9

Giandrea, M. D., Cahill, K. E., Quinn, J. F. (2008) "Self-Employment Transitions among Older American Workers with Career Jobs", BLS Working Papers, U. S. Department of Labor, U. S. Bureau of Labor Statistics, Office of Productivity and Technology, Washington, USA, Working Paper 418. [online] Available at: https://www.bls.gov/ osmr/pdf/ec080040.pdf [Accessed: 17 May 2018]

Gosling, J., Naim, M., Fearne, A., Fowler, N. (2007) "Defining the lean and agile characteristics of engineer-to-order construction projects", In: CME 2007 Conference - Construction Management and Economics: "Past, Present and Future", Reading, United Kingdom, pp. 773-785. [online] Available at: http://www.scopus.com/ inward/record.url?eid=2-s2.0-84877592573\&partnerID $=40 \& \mathrm{~m}-$ d5=526172bddf7a94f969a5728473db7f03 [Accessed: 17 May 2018]

Halligan, D. W., Demsetz, L. A., Brown, J. D., Pace, C. B. (1994) "ActionResponse Model and Loss of Productivity in Construction", Journal of Construction Engineering and Management, 120(1), pp. 47-64. [online] Available at: https://ascelibrary.org/ doi/pdf/10.1061/\%28ASCE\%290733-9364\%281994\%29120 \%3A1\%2847\%29 [Accessed: 17 May 2018]

Hiyassat, M. A., Hiyari, M. A., Sweis, G. J. (2016) "Factors affecting construction labour productivity: a case study of Jordan", International Journal of Construction Management, 16(2), pp. 138-149. https://doi.org/10.1080/15623599.2016.1142266
Iyer, K. C., Jha, K. N. (2005) "Factors affecting cost performance: Evidence from Indian construction projects", International Journal of Project Management, 23(4), pp. 283-295. https://doi.org/10.1016/j.ijproman.2004.10.003

Jarkas, A. M., Al Balushi, R. A., Raveendranath, P. K. (2015) "Determinants of construction labour productivity in Oman", International Journal of Construction Management, 15(4), pp. 332-344. https://doi.org/10.1080/15623599.2015.1094849

Jarkas, A. M., Horner, R. M. W. (2015) "Creating a baseline for labour productivity of reinforced concrete building construction in Kuwait", Construction Management and Economics, 33(8), pp. 625-639. https://doi.org/10.1080/01446193.2015.1085651

Jarkas, A. M., Kadri, C. Y., Younes, J. H. (2012) "A Survey of Factors Influencing the Productivity of Construction Operatives in the State of Qatar", International Journal of Construction Management, 12(3), pp. 1-23. https://doi.org/10.1080/15623599.2012.10773192

Jones, N. S., Slinn, D. J. (1956) "The Fauna and Biomass of a Muddy Sand Deposit off Port Erin, Isle of Man: With an Appendix on Methods Used for the Analysis of Deposits", Journal of Animal Ecology, 25(2), pp. 217-252. https://doi.org/10.2307/1924

Kaming, P. F., Olomolaiye, P. O., Holt, G. D., Harris, F. C. (1997) "Factors influencing craftsmen's productivity in Indonesia", International Journal of Project Management, 15(1), pp. 21-30. https://doi.org/10.1016/S0263-7863(96)00019-1

Kisi, K. P., Mani, N., Rojas, E. M., Foster, E. T. (2017) "Optimal Productivity in Labor-Intensive Construction Operations: Pilot Study", Journal of Construction Engineering and Management, 143(3), article ID: 04016107. https://doi.org/10.1061/(ASCE)CO.1943-7862.0001257

Loosemore, M. (2014) "Improving construction productivity: a subcontractor's perspective", Engineering, Construction and Architectural Management, 21(3), pp. 245-260. https://doi.org/10.1108/ECAM-05-2013-0043

Mahamid, I. (2013) "Contractors perspective toward factors affecting labor productivity in building construction", Engineering, Construction and Architectural Management, 20(5), pp. 446-460. https://doi.org/10.1108/ECAM-08-2011-0074

Mahmood, S., Ahmed, S. M., Panthi, K., Ishaque Kureshi, N. (2014) "Determining the cost of poor quality and its impact on productivity and profitability", Built Environment Project and Asset Management, 4(3), pp. 296-311. https://doi.org/10.1108/BEPAM-09-2013-0034

Mojahed, S., Aghazadeh, F. (2008) "Major factors influencing productivity of water and wastewater treatment plant construction: Evidence from the deep south USA", International Journal of Project Management, 26(2), pp. 195-202. https://doi.org/10.1016/j.ijproman.2007.06.003

Moselhi, O., Khan, Z. (2010) "Analysis of labour productivity of formwork operations in building construction", Construction Innovation, 10(3), pp. 286-303. https://doi.org/10.1108/14714171011060088

Moselhi, O., Khan, Z. (2012) "Significance ranking of parameters impacting construction labour productivity", Construction Innovation, 12(3), pp. 272-296. https://doi.org/10.1108/14714171211244541 
Muhwezi, L., Acai, J., Otim, G. (2014) "An Assessment of the Factors Causing Delays on Building Construction Projects in Uganda", International Journal of Construction Engineering and Management, 3(1), pp. 13-23. https://doi.org/10.5923/j.ijcem.20140301.02

Olomolaiye, P. O., Wahab, K. A., Price, A. D. F. (1987) "Problems influencing craftsmen's productivity in Nigeria", Building and Environment, 22(4), pp. 317-323. https://oi.org/10.1016/0360-1323(87)90024-2

Panas, A., Pantouvakis, J.-P. (2015) "Efficiency multipliers for construction productivity: A Comparative Evaluation", Organization, Technology and Management in Construction: An International Journal, 7(1), pp. 1186-1196.

https://doi.org/10.5592/otmcj.2015.1.3

Panas, A., Pantouvakis, J. P. (2010) "Evaluating Research Methodology in Construction Productivity Studies", The Built \& Human Environment Review, 3(1), Special Issue, pp. 63-85. [online] Available at: http://citeseerx.ist.psu.edu/viewdoc/download?doi=10.1.1.403.4785\&rep=rep1\&type=pdf [Accessed: 17 May 2018]

Rashid, H. (2015) "Construction Management: A Professional Approach of Factors Affecting the Labor Productivity", International Journal of Egineering and Technical Research (IJETR), 3(1), pp. 283-287.

Ruddock, L., Ruddock, S. (2011) "Evaluation of trends in the UK construction industry using growth and productivity accounts", Construction Management and Economics, 29(12), pp. 1229-1239. https://doi.org/10.1080/01446193.2011.645494

Singh, S., Dixit, S., Varshney, D. (2018) "Sustainable construction management in education sector", International Journal of Engineering and Technology, 7(2), pp. 300-304.

https://doi.org/10.14419/ijet.v7i2.9565
Tam, V. W. Y., Tam, C. M., Zeng, S. X., Ng, W. C. Y. (2007) "Towards Adoption of Prefabrication in Construction", Building and Environment, 42(10), pp. 3642-3654. https://doi.org/10.1016/j.buildenv.2006.10.003

Sveikauskas, L., Rowe, S., Mildenberger, J., Price, J., Young, A. (2016) "Productivity Growth in Construction", Journal of Construction Engineering and Management, 142(10), article ID: 0416045. https://doi.org/10.1061/(ASCE)CO.1943-7862.0001138

Wang, X., Chen, Y., Liu, B., Shen, Y., Sun, H. (2013) "A total factor productivity measure for the construction industry and analysis of its spatial difference: A case study in China", Construction Management and Economics, 31(10), pp. 1059-1071. https://doi.org/10.1080/01446193.2013.826371

Xue, X., Shen, Q., Wang, Y., Lu, J. (2008) "Measuring the Productivity of the Construction Industry in China by Using DEA-Based Malmquist Productivity Indices", Journal of Construction Engineering and Management, 134(1), pp. 64-71. https://doi.org/10.1061/(ASCE)0733-9364(2008)134:1(64)

Zeithaml, V. A. (2000) "Service quality, profitability, and the economic worth of customers: What we know and what we need to learn", Journal of the Academy of Marketing Science, 28(1), pp. 67-85. https://doi.org/10.1177/0092070300281007

Zouher Al-Sibaie, E., Alashwal, A. M., Abdul-Rahman, H., Zolkafli, U. K. (2014) "Determining the relationship between conflict factors and performance of international construction projects", Engineering, Construction and Architectural Management, 21(4), pp. 369-382. https://doi.org/10.1108/ECAM-03-2014-0034 